\title{
The Potential of Frog Skin-Derived Peptides for Development into Therapeutically-Valuable Immunomodulatory Agents
}

\author{
Jelena M. Pantic ${ }^{1}{ }^{*}$, Ivan P. Jovanovic ${ }^{1}$, Gordana D. Radosavljevic ${ }^{1}$, Nebojsa N. Arsenijevic ${ }^{1}$, \\ J. Michael Conlon ${ }^{2}$ and Miodrag L. Lukic ${ }^{1, *}$ \\ 1 Center for Molecular Medicine and Stem Cell Research, Faculty of Medical Sciences, \\ University of Kragujevac, 34000 Kragujevac, Serbia; ivanjovanovic77@gmail.com (I.P.J.); \\ perun.gr@gmail.com (G.D.R.); arne@medf.kg.ac.rs (N.N.A.) \\ 2 SAAD Centre for Pharmacy and Diabetes, School of Biomedical Sciences, University of Ulster, \\ Cromore Road, Coleraine, Northern Ireland BT52 1SA, UK; jmconlon1@gmail.com \\ * Correspondence: panticjelena55@gmail.com (J.M.P.); miodrag.lukic@medf.kg.ac.rs (M.L.L.); \\ Tel.: +381-3430-6800 (J.M.P. \& M.L.L.); Fax: +381-3430-6800-112 (J.M.P. \& M.L.L.)
}

Received: 6 November 2017; Accepted: 23 November 2017; Published: 13 December 2017

\begin{abstract}
The aim of this article is to review the immunoregulatory actions of frog skin-derived peptides in order to assess their potential as candidates for immunomodulatory or anti-inflammatory therapy. Frog skin peptides with demonstrable immunomodulatory properties have been isolated from skin secretions of a range of species belonging to the families Alytidae, Ascaphidae, Discoglossidae, Leptodactylidae, Pipidae and Ranidae. Their effects upon production of inflammatory and immunoregulatory cytokines by target cells have been evaluated ex vivo and effects upon cytokine expression and immune cell activity have been studied in vivo by flow cytometry after injection into mice. The naturally-occurring peptides and/or their synthetic analogues show complex and variable actions on the production of proinflammatory (TNF- $\alpha$, IL-1 $\beta$, IL-12, IL-23, IL-8, IFN- $\gamma$ and IL-17), pleiotropic (IL-4 and IL-6) and immunosuppressive (IL-10 and TGF- $\beta$ ) cytokines by peripheral and spleen cells, peritoneal cells and/or isolated macrophages. The effects of frenatin 2.1S include enhancement of the activation state and homing capacity of Th1-type lymphocytes and NK cells in the mouse peritoneal cavity, as well as the promotion of their tumoricidal capacities. Overall, the diverse effects of frog skin-derived peptides on the immune system indicate their potential for development into therapeutic agents.
\end{abstract}

Keywords: frog skin peptides; host defence peptides; immunomodulatory; cytokine; antimicrobial

\section{Introduction}

Antimicrobial peptides are an integral component of the system of innate immunity associated with all organisms and, in vertebrates, are abundantly produced in skin and mucosal epithelia and by some innate immune cells [1,2]. The primary role of such compounds is to create a chemical barrier as a protection from invading pathogens in the environment, and they may also act as a deterrent against ingestion by predators [3,4]. As well as their microbicidal actions, additional protective capacities of such molecules are now recognized, including their abilities to affect the host immune system [5-7]. In view of their multifunctional nature, these peptides are best regarded as host-defence peptides, rather than exclusively antimicrobial peptides, and they are generally active across species [8].

Peptides with diverse structural characteristics and biological effects are of particular importance in the host defence mechanisms of anurans (frogs and toads). To date, about 1000 such peptides, obtained primarily from frog species belonging to the Ascaphidae, Alytidae, Bombinatoridae, Hylidae, 
Hyperoliidae, Leptodactylidae, Myobatrachidae, Pipidae and Ranidae families, are included in Antimicrobial Peptide Database [9-11]. Numerous chemically-modified analogues of the frog peptides with improved pharmacological properties have been synthetized in order to increase their potential for therapeutic applications [12-14]. The frog host defence peptides are synthetized and stored in granular glands in the skin, often in very high concentrations, and are rapidly released following stress or tissue injury $[15,16]$. Naturally-occurring frog skin-derived peptides vary appreciably in their primary structure and lack any conserved domains responsible for their biological actions. However, the vast majority of frog skin peptides are cationic and contain a high proportion of hydrophobic amino acids. With a few exceptions, they lack a stable conformation in aqueous solutions, but adopt an amphipathic $\alpha$-helical structure in the environment of a phospholipid vesicle or in a membrane-mimetic solvent such as $50 \%$ trifluoroethanol-water [9].

Frog skin host defence peptides have been shown to display a wide range of biological effects in mammals. They were first recognized not only for their wide ranging antimicrobial (antibacterial, antifungal, anti-protozoal and antiviral) effects, but also for their ability to permeabilize mammalian cells [11]. In the absence of recognized conserved domains, as well as specific receptors responsible for their antimicrobial and cytotoxic effects, the mechanism of action of the peptides generally involves direct disruption of the cell membrane $[17,18]$. The microbicidal actions of frog skin peptides against multidrug-resistant pathogens have attracted considerable attention, and numerous synthetic analogues with increased antimicrobial potency, decreased toxicity and longer half-lives in circulation have been evaluated [19]. The therapeutic potential of frog skin host defence peptides is not confined to their role as antimicrobial agents. Several compounds have been proposed as anti-cancer agents based on their selective cytotoxicity against various tumour cells [20]. Anti-cancer effects of the peptides arise from direct disruption of the tumour cell membrane, but may also involve the induction of apoptotic cell death or the inhibition of tumour angiogenesis [21,22]. Additionally, it has been suggested that some frog skin peptides have the potential for development into agents for type 2 diabetes therapy (reviewed in [23,24]). The peptides exhibit anti-diabetogenic effects in various in vitro and in vivo experimental models, including the ability to increase insulin secretion and insulin sensitivity, improved glucose tolerance, suppression of glucagon release, enhanced $\beta$-cell proliferation, protection against $\beta$-cell apoptosis, as well as improved lipid status.

Host defence peptides are involved in the stimulation of the protective immune response, while suppressing the harmful inflammatory response [5-7]. The organizations of amphibian and mammalian immune systems share numerous similarities in terms of the functions of both innate and adaptive immunity $[25,26]$. Genes encoding proinflammatory cytokines, such as interleukin (IL)-1, IL-6, tumour necrosis factor (TNF)- $\alpha$ and interferon (IFN)- $\gamma$, are present in the genome of Xenopus tropicalis (formerly Silurana tropicalis), and activation of skin macrophages in response to extracellular pathogens has been reported $[25,27]$. In addition, dermal peptides are important participants in epithelial tissue repair following injury in both Amphibia and mammals [28]. An early indication that frog skin host defence peptides might be involved in the control of immune response is related to their chemoattractant properties. It was observed that temporin A and related peptides enhance pertussis toxin-dependent influx of phagocytes, including macrophages, monocytes and neutrophils [29].

This article evaluates the immunomodulatory potential of a range of naturally-occurring frog skin peptides, as well as their synthetic analogues. Effects on the production of various cytokines of innate and/or adaptive immunity are determined using different immune cell cultures including mouse peritoneal cells, isolated macrophages and spleen cells and human peripheral mononuclear (PBM) cells, with and without concomitant stimulation with lipopolysaccharide (LPS) or concanavalin A (Con A). Assessment of immunomodulatory effects of frog skin peptides in vivo involves an examination of their abilities to promote immune cells' influx and activation status in different strains of mice. The species from which frog skin immunomodulatory peptides have been isolated are summarized in Table 1 , and the primary structures of the peptides are shown in Table 2. 
Table 1. Species, common names and families of the frogs from which immunomodulatory peptides have been isolated.

\begin{tabular}{ccc}
\hline Species & Common Name & Family \\
\hline Ascaphus truei & Tailed frog & Ascaphidae \\
Alytes obstetricans & Midwife toad & Alytidae \\
Discoglossus sardus & Tyrrhenian painted frog & Alytidae \\
Rhinophrynus dorsalis & Mexican burrowing toad & Rhinophrynidae \\
Hymenochirus boettgeri & Congo dwarf clawed frog & Pipidae \\
Pseudhymenochirus merlini & Merlin's clawed frog & Pipidae \\
Xenopus tropicalis & Tropical clawed frog & Pipidae \\
Xenopus muelleri & Mueller's clawed frog & Pipidae \\
Xenopus amieti & Volcano clawed frog & Pipidae \\
Hoplobatrachus rugulosus & Vietnamese lowland frog & Dicroglossidae \\
Hoplobatrachus occipitalis & African crowned bullfrog & Dicroglossidae \\
Leptodactylus laticeps & Sante Fe frog & Leptodactylidae \\
Sphaenorhynchus lacteus & Orinoco lime frog & Hylidae \\
Hylarana guentheri & Guenther's frog & Ranidae \\
Hylarana erythraea & Green Paddy frog & Ranidae \\
Lithobates vaillanti & Vaillant's frog & Ranidae \\
Lithobates chiricahuensis & Chiricahua leopard frog & Ranidae \\
Rana draytonii & California red-legged frog & Ranidae \\
\hline
\end{tabular}


Table 2. Diverse effects of frog skin-derived peptides on cytokine production by human and murine cells.

\begin{tabular}{|c|c|c|c|c|}
\hline Peptide & Primary Structure & $\begin{array}{c}\text { Peritoneal Cells (PC) and/or Isolated } \\
\text { Macrophages (M) }\end{array}$ & $\begin{array}{c}\text { Spleen Cells (SC) and/or Human } \\
\text { Peripheral Mononuclear Cells (hPMC) }\end{array}$ & Ref. \\
\hline [D4k]ascaphin-8 & GFKkLLKGAAKALVKT VLF $^{a}$ & n.d. & TNF- $\alpha \downarrow$, IFN- $\gamma \downarrow$ (hPMC) & {$[30]$} \\
\hline Alyteserin-2a & ILGKLLSTAAGLLSNL $^{a}$ & n.d. & IL- $10 \downarrow$, TGF- $\beta \downarrow$ (hPMC) & {$[31]$} \\
\hline Frenatin-2D & 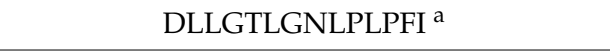 & TNF- $\alpha \uparrow, I L-1 \beta \uparrow, I L-12 \uparrow(\mathrm{M})$ & n.d. & {$[32]$} \\
\hline $\begin{array}{l}\text { Frenatin } 2.1 \mathrm{~S} \\
\text { Frenatin } 2.2 \mathrm{~S}\end{array}$ & $\begin{array}{l}\text { GLVGTLLGHIGKAILG }^{\mathrm{a}} \\
\text { GLVGTLLGHIGKAILS }^{\mathrm{a}}\end{array}$ & 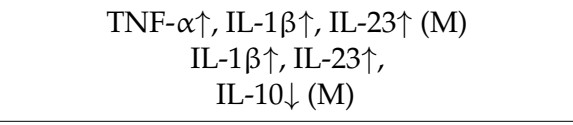 & n.d. & {$[33]$} \\
\hline Plasticin-L1 & GLVNGLLSSVLGGGQGGGGLLGGIL & TNF- $\alpha \uparrow, \mathrm{IL}-1 \beta \uparrow, \mathrm{IL}-12 \uparrow, \mathrm{IL}-23 \uparrow, \mathrm{IL}-6 \uparrow(\mathrm{M})$ & n.d. & {$[34]$} \\
\hline Tigerinin-1R & RVCSAIPLPICH $^{a}$ & $\mathrm{IL}-10 \uparrow, \mathrm{IL}-6 \uparrow(\mathrm{M})$ & IL-10个 (SC, hPMC) & [35] \\
\hline Tigerinin-1V & RICYAMWIPYPC & $\mathrm{IL}-10 \uparrow, \mathrm{IL}-6 \uparrow(\mathrm{M})$ & IL-10个 (SC, hPMC), IFN- $\gamma \downarrow$ (SC) & [35] \\
\hline Tigerinin-1M & WCPPMIPLCSRF $^{\text {a }}$ & $\mathrm{IL}-10 \uparrow(\mathrm{M}), \mathrm{IL}-6 \uparrow(\mathrm{M})$ & IL-10个 (SC, hPMC), IFN- $\gamma \downarrow$ (SC) & [35] \\
\hline $\begin{array}{l}\text { Tigerinin-1O } \\
\text { Tigerinin-2O } \\
\text { Tigerinin-3O } \\
\text { Tigerinin-4O }\end{array}$ & $\begin{array}{l}\text { RICTPIPFPMCY } \\
\text { RTCIPIPLVMC } \\
\text { RICTAIPLPMCL } \\
\text { RTCIPIPPVCF }\end{array}$ & IFN- $\gamma \downarrow$ (PC) & n.d. & [36] \\
\hline Rhinophrynin-27 & ELRLPEIARPVPEVLPARLPLPALPRN & TNF- $\alpha \downarrow$ (M) & n.d. & {$[37,38]$} \\
\hline $\begin{array}{c}{[\mathrm{E} 6 \mathrm{k}, \mathrm{D} 9 \mathrm{k}]} \\
\text { hymenochirin-1B }\end{array}$ & IKLSPETKDNLKKVLKGAI AVAKMV a & n.d. & 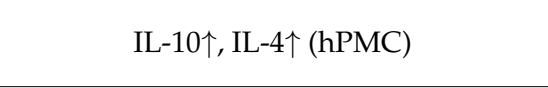 & [39] \\
\hline $\begin{array}{l}\text { Pseudhymenochirin- } 1 \mathrm{~Pb} \\
\text { Pseudhymenochirin- } 2 \mathrm{~Pa}\end{array}$ & $\begin{array}{l}\text { IKIPSFFRNILKKVGKEAVSLIAGALKQS } \\
\text { GIFPIFAKLLGKVIKVASSLISKGRTE }\end{array}$ & 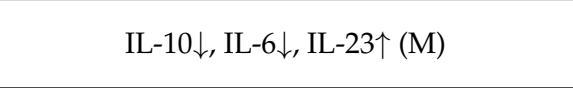 & n.d. & [40] \\
\hline [G4K]XT-7 & GLLKPLLKIAAKVGSN LL ${ }^{a}$ & n.d. & TNF- $\alpha \downarrow$ (hPMC) & [30] \\
\hline Magainin-AM1 & GIKEFAHSLGKFGKAFVGGILNQ & IL-8个 (oral fibroblasts) & n.d. & [41] \\
\hline Brevinin-2GU & GVIIDTLKGAAKTVAAELLRKAHCKLTNSC & n.d. & TNF- $\alpha \downarrow$, IFN- $\gamma \downarrow$ (hPMC) & [30] \\
\hline B2RP-ERa & GVIKSVLKGVAKTVAL GML ${ }^{a}$ & n.d. & TNF- $\alpha \downarrow$, TGF- $\beta \uparrow$, IL- $4 \uparrow$, IL-10个 (hPMC) & [30] \\
\hline [T5k]temporin-DRa & HFLGkLVNLAKKIL ${ }^{a}$ & n.d. & TNF- $\alpha \downarrow$, TGF- $\beta \uparrow$, IL- $4 \uparrow$, IL-10个 (hPMC) & {$[30]$} \\
\hline Esculentin-2CHa & GFSSIFRGVAKFASKGLGKDLAKLGVDLVAC & $\mathrm{TNF}-\alpha \uparrow(\mathrm{M})$ & $\mathrm{IL}-10 \uparrow(\mathrm{SC})$ & [42] \\
\hline
\end{tabular}

n.d., not determined; ${ }^{\text {a }}$ denotes $C$-terminal $\alpha$-amidation. 


\section{Frog Skin Peptides with Predominantly Immunostimulatory Activity that Lack Antimicrobial Activity}

Frenatin 2D, first isolated from norepinephrine-stimulated skin secretions of the Tyrrhenian painted frog Discoglossus sardus (Alytidae), did not show any microbicidal or haemolytic activity at concentrations of up to $300 \mu \mathrm{M}$ [32]. At a concentration of $20 \mu \mathrm{g} / \mathrm{mL}$, the peptide enhanced the release of proinflammatory cytokines TNF- $\alpha$ and IL-1 $\beta$, but not IL-6, by mouse peritoneal macrophages. In addition, frenatin 2D stimulated the production of IL-12 in both LPS-stimulated and unstimulated murine peritoneal macrophages.

Plasticin-L1 is a glycine/leucine-rich peptide originating from norepinephrine-stimulated skin secretions of the South-American Santa Fe frog Leptodactylus laticeps (Leptodactylidae) [34]. Plasticin-L1 did not display antimicrobial activity consistent with its weak cationic nature and consequent low affinity for bacterial cell membranes. However, at a concentration of $20 \mu \mathrm{g} / \mathrm{mL}$, the peptide enhanced the production of proinflammatory IL-1 $\beta$, IL-12, IL-23 and TNF- $\alpha$ by peritoneal macrophages from both C57BL/ 6 and BALB/c mice. Plasticin-L1 increased the production of IL- 6 by macrophages in the presence or absence of LPS, without a significant effect on the anti-inflammatory IL-10 [34].

\section{Frog Skin Peptides with Predominantly Anti-Inflammatory Activity that Lack Antimicrobial Activity}

The tigerinins are a family of small, cationic, cyclic peptides, some of which contain an $\alpha$-amidated C-terminus. Tigerinin-1R from Hoplobatrachus rugulosus (Dicroglossidae) [43], tigerinin-1V from Lithobates vaillanti (Ranidae) [44] and tigerinin-1M from Xenopus muelleri (Pipidae) [45] did not exhibit any microbicidal or haemolytic actions at concentration up to $500 \mu \mathrm{g} / \mathrm{mL}$ [35]. The most striking immunomodulatory effect of the three tigerinins is a significant dose-dependent stimulation of anti-inflammatory IL-10 production by murine peritoneal macrophages and splenocytes, as well as by human peripheral blood mononuclear cells in both LPS-stimulated and unstimulated cells. In addition, the tigerinins $(20 \mu \mathrm{g} / \mathrm{mL})$ enhanced the release of IL-6 in LPS-stimulated macrophages from C57BL/6 mice, but only tigerinin-1V potentiated IL-6 production in LPS-stimulated macrophages from BALB/c mice. The effects on the production of proinflammatory IL-12 and IL-23 by macrophages from both mouse strains were less clearly defined or absent. In a population of mononuclear cells derived from mouse spleen, tigerinin-1M and $-1 \mathrm{~V}$ suppressed the production of IFN- $\gamma$, without a significant effect on IL-17 production [35]. A further four host-defence peptides belonging to the tigerinin family (tigerinin-10, tigerinin-2O, tigerinin-3O and tigerinin-4O) were isolated from skin secretions of the African crowned bullfrog Hoplobatrachus occipitalis (Dicroglossidae) [36]. These tigerinins also lacked antimicrobial and haemolytic activities, but at a concentration of $20 \mu \mathrm{g} / \mathrm{mL}$, significantly inhibited production of IFN- $\gamma$ by peritoneal cells from C57BL/ 6 mice without affecting the production of IL-10 and IL-17. Tigerinin-2O and $-4 \mathrm{O}$ inhibited IFN- $\gamma$ production at concentrations as low as $1 \mu \mathrm{g} / \mathrm{mL}$.

The skin secretions of toad Rhinophrynus dorsalis (Rhinophrynidae) are a source of the proline-arginine-rich peptides rhinophyrinin-33 and the truncated form rhinophyrinin-27, which adopt a poly-proline helical conformation rather than the more usual $\alpha$-helix [37]. Although rhinophrynin-27 shows limited structural similarity with the porcine multifunctional peptide PR-39, it does not exhibit antimicrobial or cytotoxic effects. However, preliminary investigation of the immunomodulatory effects of rhinophrynin-27 indicates a dose-dependent suppression of the production of proinflammatory TNF- $\alpha$ by murine macrophages [38].

\section{Frog Skin Peptides with Antimicrobial and Immunosuppressive Activities}

The potential of analogues of frog skin peptides, selected for the increased potency against microrganisms and decreased cytotoxicity against mammalian cells, was evaluated as candidates for the topical treatment of acne vulgaris. [D4k]ascaphin-8 [46], [G4K]XT-7 [46], [T5k]temporin-DRa [12], brevinin-2GU and B2RP-ERa, derived from peptides originally isolated from Ascaphus truei [47], Xenopus tropicalis [48], Rana draytonii [49], Hylarana guentheri [50] and Hylarana erythraea [51], inhibited 
the growth of Propionibacterium acnes, the bacterium associated with infection of the pilosebaceous unit, but showed only weak haemolytic activity against human erythrocytes [30]. [D4k]ascaphin-8, [G4K]XT-7, brevinin-2GU and B2RP-ERa (1 and $20 \mu \mathrm{g} / \mathrm{mL})$, as well as [T5k]temporin-DRa $(20 \mu \mathrm{g} / \mathrm{mL})$ significantly reduced the production of TNF- $\alpha$ from Con A-stimulated PBM cells. [D4k]ascaphin- 8 and brevinin-2GU suppressed the production of IFN- $\gamma$ from unstimulated PBM cells at concentrations of 1 and $20 \mu \mathrm{g} / \mathrm{mL}$, while [T5k]temporin-DRa and B2RP-ERa enhanced the release of anti-inflammatory transforming growth factor (TGF)- $\beta$, IL-4 and IL-10 from both unstimulated and Con A-treated PBM cells.

Hymenochirin-1B was initially isolated from skin secretions of the Congo clawed frog Hymenochirus boettgeri (Pipidae) [52]. The naturally-occurring peptide was chemically modified by substitution of several amino acids with L- or D-lysine in order to increase cationicity, without affecting amphipathicity, with a view toward obtaining an analogue with increased microbicidal, but lower haemolytic activity. [E6k,D9k]hymenochirin-1B, as well as exhibiting potent microbicidal activity against a wide range of multidrug-resistant bacteria, enhanced the production of anti-inflammatory IL- 4 and IL-10 by human PBM cells, while the effects on the production of proinflammatory TNF- $\alpha$ and IL-17 were not significant [39].

\section{Frog Skin Peptides with Antimicrobial, Cytotoxic and Immunostimulatory Activities}

Alyteserin-2 was first isolated from skin secretions of the midwife toad Alytes obstetricans (Alytidae) [53] and, in common with the majority of frog skin host defence derivatives, is positively charged and has the propensity to adopt an amphipathic $\alpha$-helical conformation. Compared with the native peptide, the analogue [G11k,N15K]alyteserin-2a showed selective cytotoxicity for a range of human tumour cell lines, and the peptide $(1 \mu \mathrm{g} / \mathrm{mL})$ significantly inhibited the release of the immune-suppressive cytokines IL-10 and TGF- $\beta$ from unstimulated and Con A-stimulated PBM cells [31].

Esculentin-2CHa was first isolated from skin of the Chiricahua leopard frog, Lithobates chiricahuensis (Ranidae) [54], and analogues of the peptide have been synthesized that show diverse biological activities depending on their cationicity, $\alpha$-helicity, hydrophobicity and amphipathicity [42]. The naturally-occurring peptide shows potent growth inhibitory activity against a range of multidrug-resistant bacteria, as well as cytotoxic activity against human erythrocytes and human non-small cell lung adenocarcinoma A549 cells. Esculentin-2CHa significantly stimulates the release of the anti-inflammatory cytokine IL-10 by mouse lymphoid cells and elevates its production after stimulation with Con A, but paradoxically also significantly stimulates production of TNF- $\alpha$ by peritoneal macrophages. Effects on IL- 6 and IL-1 $\beta$ production were not significant.

Pseudhymenochirin-1Pb and pseudhymenochirin-2Pa were isolated from skin secretions of the frog Pseudhymenochirus merlini (Pipidae) [55], and both peptides are highly cytotoxic against human erythrocytes and several human tumour cell lines and potently inhibit the growth of a range of multidrug-resistant Gram-positive and Gram-negative bacteria [40]. Both pseudhymenochirin- $1 \mathrm{~Pb}$ and pseudhymenochirin-2Pa significantly inhibit the production of the anti-inflammatory cytokine IL-10 and the multifunctional cytokine IL-6, but enhance the production of the pro-inflammatory IL-23 by both unstimulated and LPS-stimulated murine macrophages [40].

Peptide glycine-leucine-amide (PGLa)-AM1, caerulein-precursor fragment (CPF)-AM1 and magainin-AM1 are cationic amphipathic $\alpha$-helical peptides originally isolated from norepinephrine-stimulated skin secretions of the African volcano frog Xenopus amieti (Pipidae) [56] that exhibit relatively high growth-inhibitory activity against several oral and respiratory pathogens [41]. Production of the pro-inflammatory cytokine IL-8 by oral fibroblasts was significantly increased following treatment with magainin-AM1, but not by treatment with PGLa-AM1 or CPF-AM1.

Three structurally-related peptides belonging to the frenatin family (frenatin 2.1S, 2.2S and 2.3S) were isolated from skin secretions of the Orinoco lime tree frog Sphaenorhynchus lacteus (Hylidae) [33]. Frenatin $2.1 S$ and $2.2 S$ are $C$-terminally $\alpha$-amidated glycine/leucine-rich peptides, while frenatin 
2.3S lacks an amidated C-terminus. Frenatin 2.1S and 2.2S are active against methicillin-resistant Staphylococcus aureus (MRSA) and Staphylococcus epidermidis and are cytotoxic against non-small cell lung adenocarcinoma A549 cells. An immunostimulatory effect of frenatin 2.1S and 2.2S was documented by a significantly increased production of IL-1 $\beta$ and IL-23 by LPS-stimulated mouse peritoneal macrophages. In addition, frenatin 2.1S increased the production of proinflammatory TNF- $\alpha$, while frenatin $2.2 S$ decreased the production of anti-inflammatory IL-10 [33]. Immunostimulatory effects of frenatin 2.1S in vivo were demonstrated following intraperitoneal injection of $100 \mu \mathrm{g}$ of the peptide into C57BL/ 6 and BALB/c mice. The peptide enhanced the immunostimulatory phenotype of peritoneal cells of C57BL/6 mice by increasing the expression of early activation marker CD69 among $\mathrm{T}$ and NKT cells and CXCR3 chemokine receptor on T cells, thereby indicating their activation status, as well as the polarization of the adaptive immune response toward the Th1 phenotype. Furthermore, frenatin 2.1S favours activation of peritoneal macrophages as evaluated by increased expression of MHC II, costimulatory molecule CD86 and mannose receptor CD206 among F4/80+CD11c+ cells [57].

Further studies demonstrated that intraperitoneal injection of $100 \mu \mathrm{g}$ of frenatin $2.1 \mathrm{~S}$ markedly increased the presence of peritoneal NK cells and promoted their activation status by increasing the expression of NK cells' activation markers CD69, CD107a, NKG2D and FasL. Frenatin 2.1S enhanced the tumoricidal capacities of NK cells against the 4T1 mouse breast tumour cell line. Moreover, frenatin 2.1S promoted the presence of CD11c+ dendritic cells and CD3+ T lymphocytes in the peritoneal cavity of BALB/c mice and favoured the inflammatory phenotype of immune cells, as demonstrated by the increased presence of IL-17 and CXCR3-positive T lymphocytes and TNF- $\alpha$-expressing macrophages [58]. The immunomodulatory activities of frenatin $2.1 \mathrm{~S}$ are summarized in Table 3.

Table 3. In vivo effects of the frog skin-derived peptide frenatin 2.15 on murine peritoneal mononuclear cells.

\begin{tabular}{|c|c|c|}
\hline Immune Cells & Effects of Frenatin 2.1S Administration & Ref. \\
\hline NK cells & $\begin{array}{l}\text { Increased presence of CD3-CD49b+ NK cells } \\
\text { Activation of NK cells as evaluated by increased expression of CD69, CD107a, } \\
\text { NKG2D, FasL }\end{array}$ & [58] \\
\hline T cells & $\begin{array}{l}\text { Increased presence of CD3+ T cells } \\
\text { Activation of T cells as evaluated by increased expression of: } \\
\text { chemokine receptor CXCR3 } \\
\text { IL-17 } \\
\text { CD69 }\end{array}$ & {$[57,58]$} \\
\hline NKT cells & Activation of NKT cells as evaluated by increased expression of CD69 & [57] \\
\hline Macrophages & $\begin{array}{l}\text { Macrophage activation as evaluated by increased expression of: } \\
\text { MHC II } \\
\text { mannose receptor CD206 } \\
\text { costimulatory molecule CD } 86 \\
\text { TNF- } \alpha\end{array}$ & {$[57,58]$} \\
\hline Dendritic cells & Increased presence of CD11c+ cells & {$[57,58]$} \\
\hline
\end{tabular}

\section{Conclusions}

This article has provided evidence that several frog skin host defence peptides promote the activation of both innate and adaptive immunity as evaluated by cytokine production following in vitro challenge of macrophages and/or lymphoid cells. As well as their direct antimicrobial effects, such skin peptides may act as valuable stimulators of innate immunity in order to combat invading pathogens. Although frenatin 2D and plasticin-L1 did not show any direct antimicrobial activity, they are potent stimulators of macrophages as demonstrated by significantly increased production of proinflammatory cytokines [59]. Furthermore, several structurally-different frog skin peptides including esculentin-2 $\mathrm{CHa}$, pseudhymenochirins- $1 \mathrm{~Pb}$ and $-2 \mathrm{~Pa}$, magainin- $\mathrm{AM} 1$, as well as frenatins 
2.1S, $2.2 \mathrm{~S}$ and 2.3S, exerted both antimicrobial and immunostimulatory activities, making them even more useful candidates for development into pharmaceutical agents.

The immunostimulatory effects of [G11k,N15K]alyteserin-2a, esculentin-2CHa and pseudhymenochirins $1 \mathrm{~Pb}$ and $2 \mathrm{~Pa}$ on peritoneal macrophages are complemented by the inhibition of anti-inflammatory IL-10 production, indicating a possible role in ameliorating the innate immune response during infection. In vivo studies have implicated frenatin $2.1 \mathrm{~S}$ in promoting polarization of macrophages toward the proinflammatory M1 phenotype and T cells towards the Th1- and Th17-type of adaptive immune responses that are critically involved in eliminating extracellular and intracellular microorganisms $[60,61]$. On the other hand, the analogues [E6k,D9k]hymenochirin-1B, [D4k]ascaphin-8, [G4K]XT-7, [T5k]temporin-DRa, brevinin-2GU and B2RP-ERa kill bacteria directly, while enhancing the release of anti-inflammatory cytokines and/or suppressing the release of proinflammatory cytokines. These effects might be important both for eliminating the pathogen and providing the proper balance of immune response during infection, which might be a useful approach for sepsis therapy [62]. Future work should clarify whether immunoregulatory peptides may be useful in the cytokine storm during experimental sepsis.

Manipulation of the host immune system has long been a widely accepted approach for the treatment of various inflammatory and autoimmune diseases, as well as for suppression of tumours. IL-10 is established as a powerful suppressor of effector functions of macrophages, $\mathrm{T}$ cells and NK cells, including inhibition of Th1 cells, induction of regulatory $\mathrm{T}$ cells and production of proinflammatory cytokines and microbicidal compounds by macrophages $[63,64]$. Accordingly, there is a long-standing interest in exploiting the anti-inflammatory properties of IL-10 for immuno-intervention in autoimmune diseases [65]. Frog skin-derived tigerinins-1M, $-1 \mathrm{R}$ and $-1 \mathrm{~V}$ and $[\mathrm{E} 6 \mathrm{k}, \mathrm{D} 9 \mathrm{k}] \mathrm{hym}$ enochirin- $1 \mathrm{~B}$ are potent stimulators of IL-10, whereas tigerinins-1O, $-2 \mathrm{O}$, $-3 \mathrm{O}$ and $-4 \mathrm{O}$, rhinophrynin-27 and the analogues [D4k] ascaphin-8, [G4K]XT-7, [T5k]temporin-DRa, brevinin-2GU and B2RP-ERa suppress the production of proinflammatory cytokines contributing to the immunosuppressive properties of these peptides.

[G11k,N15K]alyteserin-2a, esculentin-2CHa, pseudhymenochirins $1 \mathrm{~Pb}$ and 2Pa, magainin-AM1 and frenatins 2.1S, $2.2 \mathrm{~S}$ and $2.3 \mathrm{~S}$ are themselves directly cytotoxic for several human tumour cell lines, but their potential for anti-cancer activities may also involve their immunostimulatory properties [66]. The best studied peptide, frenatin 2.1S, is an enhancer of inflammatory phenotypes of mononuclear cells, including proinflammatory M1 macrophages, T and NKT cells. NK cells are crucial participants in the protection against infections and tumours mainly as a result of their powerful cytolytic machinery $[67,68]$. The most pronounced effect of frenatin $2.1 \mathrm{~S}$ is accumulation of NK cells, as well as promotion of their activation and tumoricidal capacities following application in vivo.

Overall, it is clear that the frog skin host defence peptides, through the combined antimicrobial, cytotoxic and immunomodulatory activities, show potential for development into agents to treat infections, inflammatory and autoimmune diseases, as well as for anti-cancer therapy. Despite the fact that the magainin analogue, pexiganan, showed initial promise for treatment of infected foot ulcers in patients with diabetes [69], the potential of frog skin peptides as therapeutic agents has not been realized. No peptides based on their structures have yet been adopted in clinical practice either as anti-infective agents or as anti-inflammatory drugs. At this time, the promotion of wound healing appears to be the most promising application for frog skin peptides because of their abilities to prevent microbial invasion, reduce inflammation and induce migration of keratinocytes [70]. Several candidates have shown therapeutic relevance $[28,71,72]$. Obstacles to such applications include the cytotoxicity of many frog skin peptides for healthy human cells, as well as their short half-lives in circulation. Further investigations are needed to create long-acting analogues of the peptides that exhibit decreased cytolytic actions against human cells. Several strategies have evolved to increase the stability of peptide-based agents by increasing their resistance to degradation by peptidases. These include incorporation of D-amino acids or unnatural amino acids such as $\alpha$-aminoisobutyric acid into the molecule and coupling of the peptide to a fatty acid such as palmitate or octanoate or to 
polyethylene glycol (reviewed in [73]). Furthermore, the mechanisms by which frog skin peptides exert their immunomodulatory actions are still obscure. Consequently, further studies are needed to elucidate the nature of the interaction of the peptide with the immune cell membrane and its effect on intracellular signaling pathways.

Acknowledgments: This work was supported by the Ministry of Education, Science and Technological Development, Belgrade, Serbia (ON 175069 and ON 175071) and the Faculty of Medical Sciences, University of Kragujevac (JP 08/15).

Author Contributions: All authors (J.M.P., I.P.J., G.D.R., N.N.A., J.M.C., M.L.L.) participated in the writing of the article and approved the final version.

Conflicts of Interest: The authors declare no conflict of interest.

\section{References}

1. Diamond, G.; Beckloff, N.; Weinberg, A.; Kisich, K.O. The Roles of Antimicrobial Peptides in Innate Host Defense. Curr. Pharm. Des. 2009, 15, 2377-2392. [CrossRef] [PubMed]

2. Zasloff, M. Antimicrobial peptides of multicellular organisms. Nature 2002, 415, 389-395. [CrossRef] [PubMed]

3. Mangoni, M.L. Host-defense peptides: From biology to therapeutic strategies. Cell. Mol. Life Sci. 2011, 68, 2157-2159. [CrossRef] [PubMed]

4. Harder, J.; Schroder, J.M. Antimicrobial peptides in human skin. Chem. Immunol. Allergy 2005, 86, $22-41$. [CrossRef] [PubMed]

5. Semple, F.; Dorin, J.R. beta-Defensins: Multifunctional modulators of infection, inflammation and more? J. Innate Immun. 2012, 4, 337-348. [CrossRef] [PubMed]

6. Haney, E.F.; Hancock, R.B. Peptide design for antimicrobial and immunomodulatory applications. Biopolymers 2013, 100, 572-583. [CrossRef] [PubMed]

7. Mansour, S.C.; Pena, O.M.; Hancock, R.E. Host defense peptides: Front-line immunomodulators. Trends Immunol. 2014, 35, 443-450. [CrossRef] [PubMed]

8. Yeung, A.T.; Gellatly, S.L.; Hancock, R.E. Multifunctional cationic host defence peptides and their clinical applications. Cell. Mol. Life Sci. 2011, 68, 2161-2176. [CrossRef] [PubMed]

9. Wang, G.; Li, X.; Wang, Z. APD3: The antimicrobial peptide database as a tool for research and education. Nucleic Acids Res. 2016, 44, D1087-D1093. [CrossRef] [PubMed]

10. Conlon, J.M. Structural diversity and species distribution of host-defense peptides in frog skin secretions. Cell. Mol. Life Sci. 2011, 68, 2303-2315. [CrossRef] [PubMed]

11. Xu, X.; Lai, R. The chemistry and biological activities of peptides from amphibian skin secretions. Chem. Rev. 2015, 115, 1760-1846. [CrossRef] [PubMed]

12. Conlon, J.M.; Al-Ghaferi, N.; Abraham, B.; Leprince, J. Strategies for transformation of naturally-occurring amphibian antimicrobial peptides into therapeutically valuable anti-infective agents. Methods 2007, 42, 349-357. [CrossRef] [PubMed]

13. Jiang, Z.; Vasil, A.I.; Hale, J.D.; Hancock, R.E.; Vasil, M.L.; Hodges, R.S. Effects of net charge and the number of positively charged residues on the biological activity of amphipathic alpha-helical cationic antimicrobial peptides. Biopolymers 2008, 90, 369-383. [CrossRef] [PubMed]

14. Matsuzaki, K. Control of cell selectivity of antimicrobial peptides. Biochim. Biophys. Acta 2009, 1788, 1687-1692. [CrossRef] [PubMed]

15. Mangoni, M.L. Temporins, anti-infective peptides with expanding properties. Cell. Mol. Life Sci. 2006, 63, 1060-1069. [CrossRef] [PubMed]

16. Conlon, J.M. The contribution of skin antimicrobial peptides to the system of innate immunity in anurans. Cell Tissue Res. 2011, 343, 201-212. [CrossRef] [PubMed]

17. Almeida, P.F.; Pokorny, A. Mechanisms of antimicrobial, cytolytic, and cell-penetrating peptides: From kinetics to thermodynamics. Biochemistry 2009, 48, 8083-8093. [CrossRef] [PubMed]

18. Huang, Y.; Huang, J.; Chen, Y. Alpha-helical cationic antimicrobial peptides: Relationships of structure and function. Protein Cell 2010, 1, 143-152. [CrossRef] [PubMed] 
19. Conlon, J.M.; Mechkarska, M. Host-defense peptides with therapeutic potential from skin secretions of frogs from the family pipidae. Pharmaceuticals 2014, 7, 58-77. [CrossRef] [PubMed]

20. Lu, C.X.; Nan, K.J.; Lei, Y. Agents from amphibians with anticancer properties. Anticancer Drugs 2008, 19, 931-939. [CrossRef] [PubMed]

21. Mader, J.S.; Hoskin, D.W. Cationic antimicrobial peptides as novel cytotoxic agents for cancer treatment. Expert Opin. Investig. Drugs 2006, 15, 933-946. [CrossRef] [PubMed]

22. Mulder, K.C.; Lima, L.A.; Miranda, V.J.; Dias, S.C.; Franco, O.L. Current scenario of peptide-based drugs: The key roles of cationic antitumor and antiviral peptides. Front. Microbiol. 2013, 4, 321. [CrossRef] [PubMed]

23. Conlon, J.M.; Mechkarska, M.; Lukic, M.L.; Flatt, P.R. Potential therapeutic applications of multifunctional host-defense peptides from frog skin as anti-cancer, anti-viral, immunomodulatory, and anti-diabetic agents. Peptides 2014, 57, 67-77. [CrossRef] [PubMed]

24. Conlon, J.M.; Mechkarska, M.; Abdel-Wahab, Y.H.; Flatt, P.R. Peptides from frog skin with potential for development into agents for Type 2 diabetes therapy. Peptides 2017, in press. [CrossRef] [PubMed]

25. Robert, J.; Ohta, Y. Comparative and developmental study of the immune system in Xenopus. Dev. Dyn. 2009, 238, 1249-1270. [CrossRef] [PubMed]

26. Colombo, B.M.; Scalvenzi, T.; Benlamara, S.; Pollet, N. Microbiota and mucosal immunity in amphibians. Front. Immunol. 2015, 6, 111. [CrossRef] [PubMed]

27. Fremont-Rahl, J.J. Mycobacterium liflandii outbreak in a research colony of Xenopus (Silurana) tropicalis frogs. Vet. Pathol. 2011, 48, 856-867. [CrossRef] [PubMed]

28. Di Grazia, A.; Cappiello, F.; Imanishi, A.; Mastrofrancesco, A.; Picardo, M.; Paus, R.; Mangoni, M.L. The frog skin-derived antimicrobial peptide esculentin-1a(1-21) $\mathrm{NH}_{2}$ promotes the migration of human HaCaT keratinocytes in an EGF receptor-dependent manner: A novel promoter of human skin wound healing? PLoS ONE 2015, 10, e0128663. [CrossRef] [PubMed]

29. Chen, Q.; Wade, D.; Kurosaka, K.; Wang, Z.Y.; Oppenheim, J.J.; Yang, D. Temporin A and related frog antimicrobial peptides use formyl peptide receptor-like 1 as a receptor to chemoattract phagocytes. J. Immunol. 2004, 173, 2652-2659. [CrossRef] [PubMed]

30. Popovic, S.; Urbán, E.; Lukic, M.; Conlon, J.M. Peptides with antimicrobial and anti-inflammatory activities that have therapeutic potential for treatment of acne vulgaris. Peptides 2012, 34, 275-282. [CrossRef] [PubMed]

31. Conlon, J.M.; Mechkarska, M.; Prajeep, M.; Arafat, K.; Zaric, M.; Lukic, M.L.; Attoub, S. Transformation of the naturally occurring frog skin peptide, alyteserin-2a into a potent, non-toxic anti-cancer agent. Amino Acids 2013, 44, 715-723. [CrossRef] [PubMed]

32. Conlon, J.M.; Mechkarska, M.; Pantic, J.M.; Lukic, M.L.; Coquet, L.; Leprince, J.; Nielsen, P.F.; Rinaldi, A.C. An immunomodulatory peptide related to frenatin 2 from skin secretions of the Tyrrhenian painted frog Discoglossus sardus (Alytidae). Peptides 2013, 40, 65-71. [CrossRef] [PubMed]

33. Conlon, J.M.; Mechkarska, M.; Radosavljevic, G.; Attoub, S.; King, J.D.; Lukic, M.L.; McClean, S. A family of antimicrobial and immunomodulatory peptides related to the frenatins from skin secretions of the Orinoco lime frog Sphaenorhynchus lacteus (Hylidae). Peptides 2014, 56, 132-140. [CrossRef] [PubMed]

34. Scorciapino, M.A.; Manzo, G.; Rinaldi, A.C.; Sanna, R.; Casu, M.; Pantic, J.M.; Lukic, M.L.; Conlon, J.M. Conformational analysis of the frog skin peptide, plasticin-L1, and its effects on production of proinflammatory cytokines by macrophages. Biochemistry 2013, 52, 7231-7241. [CrossRef] [PubMed]

35. Pantic, J.M.; Mechkarska, M.; Lukic, M.L.; Conlon, J.M. Effects of tigerinin peptides on cytokine production by mouse peritoneal macrophages and spleen cells and by human peripheral blood mononuclear cells. Biochimie 2014, 101, 83-92. [CrossRef] [PubMed]

36. McLaughlin, C.M.; Lampis, S.; Mechkarska, M.; Coquet, L.; Jouenne, T.; King, J.D.; Mangoni, M.L.; Lukic, M.L.; Scorciapino, M.A.; Conlon, J.M. Purification, conformational analysis, and properties of a Family of tigerinin peptides from skin secretions of the crowned bullfrog Hoplobatrachus occipitalis. J. Nat. Prod. 2016, 79, 2350-2356. [CrossRef] [PubMed]

37. Conlon, J.M.; Guilhaudis, L.; Leprince, J.; Coquet, L.; Mangoni, M.L.; Attoub, S.; Jouenne, T.; King, J.D. Peptidomic analysis of skin secretions of the Mexican burrowing toad Rhinophrynus dorsalis (Rhinophrynidae): Insight into the origin of host-defense peptides within the Pipidae and characterization of a proline-arginine-rich peptide. Peptides 2017, 97, 22-28. [CrossRef] [PubMed] 
38. Pantic, J.M.; Jovanovic, I.P.; Radosavljevic, G.D.; Arsenijevic, N.N.; Conlon, J.M.; Lukic, M.L. Regulatory effects of rhinophrynin-27 on cytokine production by macrophages. In preparation.

39. Mechkarska, M.; Prajeep, M.; Radosavljevic, G.D.; Jovanovic, I.P.; Al Baloushi, A.; Sonnevend, A.; Lukic, M.L.; Conlon, J.M. An analogue of the host-defense peptide hymenochirin-1B with potent broad-spectrum activity against multidrug-resistant bacteria and immunomodulatory properties. Peptides 2013, 50, 153-159. [CrossRef] [PubMed]

40. Mechkarska, M.; Attoub, S.; Sulaiman, S.; Pantic, J.; Lukic, M.L.; Conlon, J.M. Anti-cancer, immunoregulatory, and antimicrobial activities of the frog skin host-defense peptides pseudhymenochirin- $1 \mathrm{~Pb}$ and pseudhymenochirin-2Pa. Regul. Pept. 2014, 194-195, 69-76. [CrossRef] [PubMed]

41. McLean, D.T.; McCrudden, M.T.; Linden, G.J.; Irwin, C.R.; Conlon, J.M.; Lundy, F.T. Antimicrobial and immunomodulatory properties of PGLa-AM1, CPF-AM1, and magainin-AM1: Potent activity against oral pathogens. Regul. Pept. 2014, 194-195, 63-68. [CrossRef] [PubMed]

42. Attoub, S.; Mechkarska, M.; Sonnevend, A.; Radosavljevic, G.; Jovanovic, I.; Lukic, M.L.; Conlon, J.M. Esculentin-2CHa: A host-defense peptide with differential cytotoxicity against bacteria, erythrocytes and tumor cells. Peptides 2013, 39, 95-102. [CrossRef] [PubMed]

43. Ojo, O.O.; Abdel-Wahab, Y.H.; Flatt, P.R.; Mechkarska, M.; Conlon, J.M. Tigerinin-1R: A potent, non-toxic insulin-releasing peptide isolated from the skin of the Asian frog, Hoplobatrachus rugulosus. Diabetes Obes. Metab. 2011, 13, 1114-1122. [CrossRef] [PubMed]

44. Conlon, J.M.; Raza, H.; Coquet, L.; Jouenne, T.; Leprince, J.; Vaudry, H.; King, J.D. Purification of peptides with differential cytolytic activities from the skin secretions of the Central American frog, Lithobates vaillanti (Ranidae). Comp. Biochem. Physiol. C Toxicol. Pharmacol. 2009, 150, 150-154. [CrossRef] [PubMed]

45. Mechkarska, M.; Ahmed, E.; Coquet, L.; Leprince, J.; Jouenne, T.; Vaudry, H.; King, J.D.; Conlon, J.M. Peptidomic analysis of skin secretions demonstrates that the allopatric populations of Xenopus muelleri (Pipidae) are not conspecific. Peptides 2011, 32, 1502-1508. [CrossRef] [PubMed]

46. Conlon, J.M.; Galadari, S.; Raza, H.; Condamine, E. Design of potent, non-toxic antimicrobial agents based upon the naturally occurring frog skin peptides, ascaphin-8 and peptide XT-7. Chem. Biol. Drug Des. 2008, 72, 58-64. [CrossRef] [PubMed]

47. Conlon, J.M.; Sonnevend, A.; Davidson, C.; Smith, D.D.; Nielsen, P.F. The ascaphins: A family of antimicrobial peptides from the skin secretions of the most primitive extant frog, Ascaphus truei. Biochem. Biophys. Res. Commun. 2004, 320, 170-175. [CrossRef] [PubMed]

48. Ali, M.F.; Soto, A.; Knoop, F.C.; Conlon, J.M. Antimicrobial peptides isolated from skin secretions of the diploid frog, Xenopus tropicalis (Pipidae). Biochim. Biophys. Acta 2002, 1550, 81-89. [CrossRef]

49. Conlon, J.M.; Al-Ghafari, N.; Coquet, L.; Leprince, J.; Jouenne, T.; Vaudry, H.; Davidson, C. Evidence from peptidomic analysis of skin secretions that the red-legged frogs, Rana aurora draytonii and Rana aurora aurora, are distinct species. Peptides 2006, 27, 1305-1312. [CrossRef] [PubMed]

50. Conlon, J.M.; Power, G.J.; Abdel-Wahab, Y.H.; Flatt, P.R.; Jiansheng, H.; Coquet, L.; Leprince, J.; Jouenne, T.; Vaudry, H. A potent, non-toxic insulin-releasing peptide isolated from an extract of the skin of the Asian frog, Hylarana guntheri (Anura:Ranidae). Regul. Pept. 2008, 151, 153-159. [CrossRef] [PubMed]

51. Al-Ghaferi, N.; Kolodziejek, J.; Nowotny, N.; Coquet, L.; Jouenne, T.; Leprince, J.; Vaudry, H.; King, J.D.; Conlon, J.M. Atimicrobial peptides from the skin secretions of the South-East Asian frog Hylarana erythraea (Ranidae). Peptides 2010, 31, 548-554. [CrossRef] [PubMed]

52. Mechkarska, M.; Prajeep, M.; Coquet, L.; Leprince, J.; Jouenne, T.; Vaudry, H.; King, J.D.; Conlon, J.M. The hymenochirins: A family of antimicrobial peptides from the Congo dwarf clawed frog Hymenochirus boettgeri (Pipidae). Peptides 2012, 35, 269-275. [CrossRef] [PubMed]

53. Conlon, J.M.; Demandt, A.; Nielsen, P.F.; Leprince, J.; Vaudry, H.; Woodhams, D.C. The alyteserins: Two families of antimicrobial peptides from the skin secretions of the midwife toad Alytes obstetricans (Alytidae). Peptides 2009, 30, 1069-1073. [CrossRef] [PubMed]

54. Conlon, J.M.; Mechkarska, M.; Coquet, L.; Jouenne, T.; Leprince, J.; Vaudry, H.; Kolodziejek, J.; Nowotny, N.; King, J.D. Characterization of antimicrobial peptides in skin secretions from discrete populations of Lithobates chiricahuensis (Ranidae) from central and southern Arizona. Peptides 2011, 32, 664-669. [CrossRef] [PubMed] 
55. Conlon, J.M.; Prajeep, M.; Mechkarska, M.; Coquet, L.; Leprince, J.; Jouenne, T.; Vaudry, H.; King, J.D. Characterization of the host-defense peptides from skin secretions of Merlin's clawed frog Pseudhymenochirus merlini: Insights into phylogenetic relationships among the Pipidae. Comp. Biochem. Physiol. Part D Genom. Proteom. 2013, 8, 352-357. [CrossRef] [PubMed]

56. Conlon, J.M.; Al-Ghaferi, N.; Ahmed, E.; Meetani, M.A.; Leprince, J.; Nielsen, P.F. Orthologs of magainin, PGLa, procaerulein-derived, and proxenopsin-derived peptides from skin secretions of the octoploid frog Xenopus amieti (Pipidae). Peptides 2010, 31, 989-994. [CrossRef] [PubMed]

57. Pantic, J.M.; Radosavljevic, G.D.; Jovanovic, I.P.; Arsenijevic, N.N.; Conlon, J.M.; Lukic, M.L. In vivo administration of the frog skin peptide frenatin 2.1S induces immunostimulatory phenotypes of mouse mononuclear cells. Peptides 2015, 71, 269-275. [CrossRef] [PubMed]

58. Pantic, J.M.; Jovanovic, I.P.; Radosavljevic, G.D.; Gajovic, N.M.; Arsenijevic, N.N.; Conlon, J.M.; Lukic, M.L. The frog skin host-defense peptide frenatin 2.1S enhances recruitment, activation and tumoricidal capacity of NK cells. Peptides 2017, 93, 44-50. [CrossRef] [PubMed]

59. Lin, W.W.; Karin, M.A. A cytokine-mediated link between innate immunity, inflammation, and cancer. J. Clin. Investig. 2007, 117, 1175-1183. [CrossRef] [PubMed]

60. Mills, C.D.; Kincaid, K.; Alt, J.M.; Heilman, M.J.; Hill, A.M. M-1/M-2 macrophages and the Th1/Th2 paradigm. J. Immunol. 2000, 164, 6166-6173. [CrossRef] [PubMed]

61. Damsker, J.M.; Hansen, A.M.; Caspi, R.R. Th1 and Th17 cells: Adversaries and collaborators. Ann. N. Y. Acad. Sci. 2010, 1183, 211-221. [CrossRef] [PubMed]

62. Hotchkiss, R.S.; Monneret, G.; Payen, D. Sepsis-induced immunosuppression: From cellular dysfunctions to immunotherapy. Nat. Rev. Immunol. 2013, 13, 862-874. [CrossRef] [PubMed]

63. Moore, K.W.; de Waal Malefyt, R.; Coffman, R.L.; O'Garra, A. Interleukin-10 and the interleukin-10 receptor. Annu. Rev. Immunol. 2001, 19, 683-765. [CrossRef] [PubMed]

64. Groux, H.; Bigler, M.; De Vries, J.E.; Roncarolo, M.G. Interleukin-10 induces a long-term antigen specific anergic state in human CD4+ T cells. J. Exp. Med. 1996, 184, 19-29. [CrossRef] [PubMed]

65. Adorini, L. Cytokine-based immunointervention in the treatment of autoimmune diseases. Clin. Exp. Immunol. 2003, 132, 185-192. [CrossRef] [PubMed]

66. Vacchelli, E.; Aranda, F.; Bloy, N.; Buqué, A.; Cremer, I.; Eggermont, A.; Fridman, W.H.; Fucikova, J.; Galon, J.; Spisek, R.; et al. Trial Watch-Immunostimulation with cytokines in cancer therapy. Oncoimmunology 2015, 5, e1115942. [CrossRef] [PubMed]

67. Waldhauer, I.; Steinle, A. NK cells and cancer immunosurveillance. Oncogene 2008, 27, 5932-5943. [CrossRef] [PubMed]

68. Vivier, E.; Tomasello, E.; Baratin, M.; Walzer, T.; Ugolini, S. Functions of natural killer cells. Nat. Immunol. 2008, 9, 503-510. [CrossRef] [PubMed]

69. Lipsky, B.A.; Holroyd, K.J.; Zasloff, M. Topical versus systemic antimicrobial therapy for treating mildly infected diabetic foot ulcers: A randomized, controlled, double-blinded, multicenter trial of pexiganan cream. Clin. Infect. Dis. 2008, 47, 1537-1545. [CrossRef] [PubMed]

70. Mangoni, M.L.; McDermott, A.M.; Zasloff, M. Antimicrobial peptides and wound healing: Biological and therapeutic considerations. Exp. Dermatol. 2016, 25, 167-173. [CrossRef] [PubMed]

71. Li, X.; Wang, Y.; Zou, Z.; Yang, M.; Wu, C.; Su, Y.; Tang, J.; Yang, X. OM-LV20, a novel peptide from odorous frog skin, accelerates wound healing in vitro and in vivo. Chem. Biol. Drug Des. 2017, in press. [CrossRef] [PubMed]

72. Liu, H.; Duan, Z.; Tang, J.; Lv, Q.; Rong, M.; Lai, R. A short peptide from frog skin accelerates diabetic wound healing. FEBS J. 2014, 281, 4633-4643. [CrossRef] [PubMed]

73. Vasu, S.; McGahon, M.K.; Moffett, R.C.; Curtis, T.M.; Conlon, J.M.; Abdel-Wahab, Y.H.; Flatt, P.R. Esculentin-2CHa(1-30) and its analogueues: Stability and mechanisms of insulinotropic action. J. Endocrinol. 2017, 232, 423-435. [CrossRef] [PubMed]

(c) 2017 by the authors. Licensee MDPI, Basel, Switzerland. This article is an open access article distributed under the terms and conditions of the Creative Commons Attribution (CC BY) license (http:/ / creativecommons.org/licenses/by/4.0/). 